\title{
Emerging Trends of Viral Zoonoses: A Problem Needs Solution
}

\author{
Chandrahas Sannat ${ }^{1 *}$, Nidhi Rawat ${ }^{1}$, Amit Kumar Gupta ${ }^{1}$, \\ Poornima Gumasta ${ }^{2}$ and S. D. Hirpurkar ${ }^{1}$
}

\author{
${ }^{1}$ Department of Veterinary Microbiology, ${ }^{2}$ Department of Veterinary Pathology \\ College of Veterinary Science \& A.H., Anjora, Durg, Chhattisgarh, INDIA
}

*Corresponding author

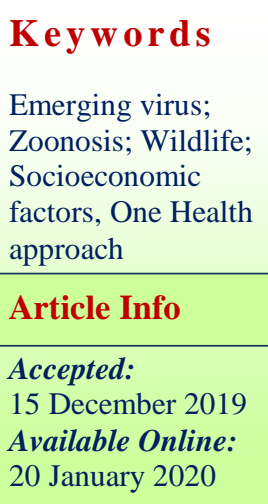

\section{A B S T R A C T}

Last few decades have been momentous in the history of human and animal health because a series of new infectious zoonotic viruses were reported and researched across the globe. More than $70 \%$ of the emerging zoonoses reported in the last decade had viral etiology and originated in wild life. Changing face of zoonotic viruses poses threat to public health and economy. The risk factors precipitating the occurrence of emerging viruses are many; and they are in a state of continuous evolution. Viruses are usually driven to emerge as a potential zoootic pathogen by changing pattern of socioeconomic and environmental factors. Wildlife is the main cradle of emerging zoonotic viruses. Therefore, they deserve additional attention in terms of surveillance to ensure an early detection and prediction of new viruses before they emerge. Retrospective analysis and baseline data of previous outbreaks serves the basis for prediction and detection of new viruses. Several actions viz. awareness campaigning, general precautions and biosecurity measures, vaccination and health management are taken simultaneously to reduce the impact of hazards. One Health approach at human-animal-ecosystem interface is vital for effective investigation, prevention and control of emerging viruses.

\section{Introduction}

Zoonotic diseases pose a major impact on human civilization throughout history and have therefore shaped socioeconomic development and farming practices throughout world. Rudolf Virchow, the most prominent physicians of the 19th century was the first to introduce the term "zoonosis" for infectious disease shared between humans and animals (Klauder, 1958). Prior to the 20th
Century, the best known zoonoses were rabies, anthrax, glanders, tuberculosis, plague, yellow fever, influenza, and certain zoonotic parasitic diseases (Blancou and Meslin, 2000). A retrospective analysis of these events generates a number of lessons regarding the emergence and recovery of these diseases. In recent years a number of new zoonoses have emerged, in both developing and developed countries, and a number of known zoonoses have reemerged 
in areas where they had been absent for decades or have spread to animal species in which the pathogens had not previously been detected.

Joint consultation of the World Health Organization/Food and Agriculture Organization/World Organisation for Animal Health on emerging zoonotic diseases, held in Geneva in May 2004, defined an emerging zoonosis as "a zoonosis that is newly recognised or newly evolved or that has occurred previously but shows an increase in incidence or expansion in geographical, host or vector range" (WHO, FAO and OIE, 2004). Public health importance has gained visibility in the last few decades due to emergence and rapid spread of newer viral zoonoses, namely Severe Acute Respiratory Syndrome (SARS), Middle East Respiratory Syndrome-Corona Virus (MERS Co-V), Nipah, Ebola, Avian Influenza (H7N9, H5N1), Crimean Congo Haemorrhagic Fever (CCHF), Zika, Kyasanur Forest Disease (KFD), Japanese Encephalitis (JE) etc. (Ryu, 2017). These viruses yielded an impact on public health and economy that poses serious challenge to socioeconomic development of nation.

Several intrinsic and extrinsic factors including pathogen adaptation, socioeconomic and environmental factors are involved in precipitation and emergence of newer viruses. Better understanding of these drivers of viral emergence can be helpful in implementation of strategies for timely detection, prevention and response.

This review therefore would discuss the recent trends of emerging viruses, precipitating risk factors involved in viral emergence and possible strategies for prediction, diagnosis and prevention of emerging viral zoonoses.
Impact and public health importance of emerging viral zoonoses

Infectious diseases remain as the major causes of human and animal morbidity and mortality leading to significant healthcare expenditure in India. An estimated $60 \%$ of human pathogens are zoonotic (Mourya et al., 2019). Roughly $80 \%$ of viruses, $50 \%$ of bacteria, $40 \%$ of fungi, $70 \%$ of protozoa and $95 \%$ of helminths that infect human beings are zoonotic (Taylor et al., 2001). Amongst emerging infections reported during 2017 by Integrated Disease surveillance programme (IDSP), 71\% constitutes viral origin while 29 per cent were due to non-viral pathogens (Mourya et al., 2019). The majority of the viral infections identified in humans over the last decade had a zoonotic background indicating that the influence of animals in human diseases has increased and is continuing to evolve (Table 1). Respiratory viral infections, arboviral infections and batborne viral infections represent three major categories of emerging viral infections in India (Mourya et al., 2019). Pandemic influenza H1N1pdm09, highly pathogenic avian influenza infection (H5N1) and the MERS-CoV represent three major pathogens transmitted through infectious aerosols. Arthropod-borne viruses such as $\mathrm{CCHF}$, dengue, chikungunya, JE and KFD have consistently been the reason of emerging and re-emerging diseases. Several bat-borne viruses have also come into major notice, such as Nipah virus, severe fever with thrombocytopenia virus (SFTV) and Ebola virus (Wang and Craneri, 2014). Emerging viral zoonoses are a growing threat to global health and have caused hundreds of billions of US dollars of economic damage in the past 20 years (Table 2).

WHO enlisted top 10 priority emerging zoonoses based on their potential to cause a public health emergency which urgently need 
accelerated research and development (WHO, 2018). All the emerging zoonoses prioritized by WHO have viral etiology i.e. CCHF, Ebola Viral Disease and Marburg Viral Disease, Lassa Fever, MERS-CoV and SARS, Nipah and henipaviral diseases, Rift Valley Fever (RVF) and Zika disease. The question then arises as to what sort of change happen that lead to rapid emergence of these viruses? To answer this question one has to understand the various intrinsic viral determinants and precipitating drivers involved in emergence of virus.

\section{Intrinsic (genetic) factors of viral emergence}

Viruses emerged during late $20^{\text {th }}$ Century and in the $21^{\text {st }}$ Century are known to have RNA as their genetic material (Table 1). RNA viruses display a potential to infect newer host species because of their intrinsic ability for genetic change. Viruses usually have multiple genes involved in cellular tropism and host range, that encode non-structural or structural viral proteins (McFadden , 2005). Modification of such genes by mutation (SARS, Influenza, Ebola) or their acquisition by recombination (SARS, MERS-CoV, Flavivirus, Enterovirus) or reassortment (Influenza A virus) unlock the path to a change in host range and disease emergence. Mutation, recombination and genetic reassortment produce complex and phenotypically diverse population of viruses (Domingo, 2010).

RNA viruses are more prone to mutation due to absence of exonuclease activity that helps in error correction which causes accumulation of point mutation over a period of time in infected host leading to development of viral quasispecies. Recombination occurs both with RNA and DNA viruses, but it is infrequent with most negative-strand RNA viruses. Molecular recombination occurs between related or unrelated viruses replicating in similar/different host species. Emergence, adaptation and rapid transmission of SARS corona viruses between bat-human-human is attributed to large genome size of virus leading to aaccumulation of point mutation over a prolonged period followed by molecular recombination of bat and civet corona viruses (Graham and Baric,2010).

Recombination and reassortment events, followed by fitness adjustments through mutation play major role in the emergence and re-emergence of new viral pathogens. It can be exemplified by emergence of 2009 pandemic H1N1 influenza which occurred by genome reassortment between european avian like H1N1, Classical Swine H1N1, Human seasonal $\mathrm{H} 3 \mathrm{~N} 2$ and north american avian H1N1 followed by amplification in pig (Neumann et al., 2009). Similarly, emergence of H7N9 in China came about through triple reassortment between domestic duck H7N3, wild bird H7N9 and domestic poultry H9N2 (www.cdc.gov). The surface antigenic glycoproteins of influenza virus undergo two major types of antigenic variation, viz. antigenic shift and antigenic drift (Nakajima, 2003). Antigenic shift is the result of major changes in one or both the surface antigens i.e. haemagglutinin (HA) and neuraminidase (NA) and occurs through exchange of segments between subtype of influenza virus. Three mechanisms might be operative in the antigenic shift, leading to emergence of pandemic influenza strains, viz. genetic reassortment, direct transfer from avian/mammalian host to humans and virus recycling. Antigenic drift results due to minor changes in HA or NA and causes frequent epidemics.

\section{Drivers of emergence}

Though the central cause of emergence of viruses are mainly attributed to genetic 
variation in viruses; the underlying drivers of emergence are largely environmental, ecological, political, economic, and social forces, functioning on a range of different scales, which facilitate the expansion and adaptation of a virus to a new niche (Smolinski et al., 2003). The first classification of drivers in the emergence of infectious diseases was published in 1992 by the Institute of Medicine (IOM) and was human demographics and behaviour, technology and industry, economic development and land use, international travel and commerce, microbial adaptation and change, and breakdown of public health measures. Seven additional drivers were further added in IOM report during $2003 \mathrm{viz}$. human susceptibility to infection, climate and weather, changing ecosystems, poverty and social inequity, war and famine, lack of political will and intent to harm.

International travel and commerce, climate change, land use change, poverty and social inequality, and human demographics and behaviour are in the state of continuous evolution and needs immediate attention. However, when ranked by primary zoonotic driver; land-use change, climate change, and international travel and commerce are globally the top three drivers of emerging viral zoonoses (Loh et al., 2015).

\section{Land use change}

Land use change includes deforestation, agriculture intensification and urbanization which opens the ground for encroachment of wild life reservoirs into human dwellings in search of feed and thereby changing the feeding preference of wild life reservoirs. Habitat change, in turn, may affect the breeding sites of disease vectors or the biodiversity of vectors or reservoir hosts. Vectors linked to wild animals start shifting to new location and adaptation of these vectors then occurs into newer host. Intensification of agriculture and modern farming practices are associated with $>25 \%$ of emerging infectious diseases and $>50 \%$ of emerging zoonotic infectious diseases in humans (Rohr et al., 2019). Emergence of JE virus may be correlated with irrigation-based agriculture and rural development that can expand breeding habitats of Culex vectors which then establishes a secondary cycle in domestic pig populations where it amplifies and spills over into human populations (Keiser et al., 2005). Similarly, expansion and changes in agricultural practices are associated with the emergence of Nipah Virus in Malaysia. Emergence of Nipah virus in Kozhikode and Mallapuram and Monkey fever in Waynad district of Kerala during 2018-19 can be linked with substantial decrease in forest land cover in Mallapuram, Kozhikode and Waynad district from 1993 to 2017 (Talukdar et al., 2018).

The burden of infectious disease in developing countries with rapid urbanization rates is extremely high, due to both overpopulation and pollution. By the year 2050 , it is estimated that world population will increase by $27 \%$ from its current 7.0 billion to 8.9 billion (Cook, 2013). Closer contact between reservoir hosts due to overpopulation creates a potential risk of the interspecies transmission (Haggett, 1994). Urbanization also favours breeding of vectors thereby emergence of vector borne viruses.

\section{Climate change}

Climate change due to global warming is known to everyone. As per recent report of world meteorological organization, an increase of $1.1{ }^{\circ} \mathrm{C}$ global surface temperature was recorded from 2010 to 2019 (public.wmo.int). Vector-borne and water borne viruses are highly sensitive to climate change as it adversely affects vector biology, 
water availability and migratory pattern of birds thereby leading to emergence of newer vector borne viruses (Wilson, 2001). Emergence of mosquito borne Rift valley fever is associated with elevated precipitation and is driven by irrigation and construction of dam and canal whereas close interaction of birds and mosquito near water bodies in draught condition may result into emergence of West Nile virusrodent bone Hanta pulmonary syndrome. Abundant rodent population due to elevated precipitation led to occurrence of Hanta pulmonary syndrome. Regular outbreaks of Japanese encephalitis in India is related with warmer weather and erratic rainfall creating breeding ground of Culex mosquito in various places of India.

\section{International travel and trade}

The number of international journey worldwide is project to increase by $3.3 \%$ a year, on average, in the period 2010-2030, in contrast to an average of $3.9 \%$ a year in the period 1995-2010 (World Tourism Organization, 2011).Through international trade, human viruses, insect vectors, and their intermediate animal hosts can be dispersed throughout the world.

Transport of animals can result in mingling of different species in crowded and stressful conditions leading to suppression of immune system, persistent infections and increase virus shedding. Under such situation, susceptible species can easily become infected. Rapid global spread of the recent 2009 H1N1 pandemic influenza, SARS, MERS-CoV, introduction of Aedes albopictus (Asian tiger mosquito) into the United States, Brazil and parts of Africa in shipments of used tyres from Asia (Centers for Disease Control, 1991) and the world-wide spread of hantaviruses by rats (LeDuc, 1992) were attributed to international travel and commerce.

\section{Recent trends of viral zoonoses Increasing incidence of vector borne viruses and their expansion in new geographical settings}

Most of the viruses emerged during last few decades are known to have arthropod transmission. Ticks and mosquito comprises major subgroup of vectors because of their short life span and their interaction with human-livestock-wildlife interface (Mansfield et al., 2017; Rossati, 2017). About 30\% of vector borne viruses are linked to wild life reservoirs (Eisen et al., 2017) which lead to rapid dissemination and persistence of vector borne viruses. Vector borne diseases due to ticks, mosquitoes and fleas have tripled from 2004 to 2016 with over 640000 cases reported during 12 years (www.cdc.gov/media/releases/2018/p0501vs-vector-borne). Major tick borne emerging viruses are $\mathrm{CCHF}$, KFD, Tick borne encephalitis and TSSF viruses; whereas mosquitoes are associated with emergence of Dengue, Chikungunya, Yellow fever,, Japanese encephalitis, West Nile fever, RVF and Zika viruses.

Emerging trends of vector borne viruses are also due to their expansion in newer geographical settings (Weaver and Reisen, 2010) because of transport of vectors due to international trade and travel and a combination of socioeconomic and environmental changes that affect vectors and wildlife hosts leading to exposure of human to vectors. Shifting of geographical settings can be better explained by retrospective case study of JE in India (Kulkarni et al., 2018). The disease was first appeared in India in 1955 and the first outbreak occurred in1973 in West Bengal. However, it was only after 1978 that the disease became widespread. Since then, the virus was found active almost in every part of India and outbreaks have been reported regularly. The most affected states comprise of Andhra Pradesh, Assam, Bihar, 
Haryana, Karnataka, Kerala, Maharashtra, Manipur, Tamil Nadu, Orissa, Uttar Pradesh and West Bengal. The state of Uttar Pradesh (UP) has been under constant surveillance for JE virus activity since 1978. The longest epidemic of viral encephalitis was reported from Gorakhpur district, UP between July and November 2005. Recently, another large outbreak is reported in Malkangiri (2012) and Manipur (2016). Now, JE is endemic in India and many countries of Asia including China and Japan. JE is detected among the rural children often between July-October of the year (rice cultivation) in view of high mosquito activity during this time. Uncontrolled swine and poultry/bird rearing and poor vaccine cover to humans pose serious risks and challenges in India.

\section{Wild life reservoir: a potential source of emerging viruses}

Emergence of non vector borne viruses is attributed to their wider host range and adaptation into newer host. More than $71 \%$ of these viruses are originated from wild life reservoirs (Jones et al., 2008). Amongst wild life; rodents are the predominant reservoir of viruses followed by bats and nonhuman primates. Hantaviruses and arenaviruses are naturally occurring viruses of rodents which causes hanta pulmonary syndrome and Lassa fever in human, respectively (Enria and Pinheiro, 2000). Bat borne viruses are among the most important of the emerging viruses (Calisher et al., 2006). There are about 17 zoonoses yet to be discovered on every bat species versus about 10 for rodent and primate species. Bats comprise more than 20\% living species (approx. 1100 species) and are the only mammals capable of powered flight with long life span (Smith and Wang, 2013). Primitive immune system in bats and echolocation creating droplet clouds facilitate the spread of viruses, which makes bats to harbour more dangerous viruses than other species (Kupferschmidt, 2017). More than
200 viruses have been associated with bats, and almost all are RNA viruses having ability to adapt to changing environment through higher genetic variability (Allocati et al., 2016). Bat borne viruses are transmitted via bat bite and transfer via saliva, feces or urine. These include Ebola, SARS, MERS-CoV, Hendra, Nipah and Marburg viruses (Wang and Anderson, 2019). Ebola, Marburg, KFD, monkey pox, yellow fever viruses are known to be transmitted through various species of non human primates (Chapman et al., 2005). Interspecies transmission of virus can be understood by studying different stages in the development of emergence. This also helps to identify specific checkpoint to apply control measures to check the emergence of new virus in the human population.

\section{Stages in development of emergence and interspecies transmission of virus}

Emergence of new virus occurs through sequential steps (Morse et al., 2012) including pre-emergence (no human infection), localized emergence (human infection, spillover); and global emergence (HumanHuman infection).

During pre-emergence stage (Stage 1), the virus exists in its natural reservoir. Ecological, social or socioeconomic changes (change in land use) alter the dynamics of virus transmission within the host or between hosts and allow the pathogen to expand within its host population, spread to a new region or be transmitted to another non-human host population or species. Each of these changes increases the likelihood of the virus making contact with human beings and thus progress to localized emergence (stage 2), during which wildlife or livestock pathogens spill over to people due to handling and slaughtering of wildlife and consumption of bush meat or through exposure to fomites in wildlife markets or livestock farms. Outcomes vary widely, from small clusters of human 
cases (Menangle virus) to large outbreaks, some with limited person-to-person transmission (Ebola virus) and some without (Hendra virus). During global/full pandemic emergence (stage 3)), sustained person-toperson transmission and large-scale spread occur, often aided by global air travel (HIV/AIDS, SARS) or the international movement of reservoir hosts or vectors through trade (West Nile virus). Stage 3 pandemics are rare because even virus capable of some person-to-person transmission might not be able to maintain long enough chains of transmission to spread (Nipah virus in Bangladesh).

\section{Targeting transmission pathway to check the emergence of virus}

Targeting and controlling stage 1 can check the emergence of new viruses, but it is not known to anyone that when and where new virus will emerge. However the retrospective analysis and baseline data of previous outbreaks may provide important starting points for making projections of human disease risk and can be therefore effectively applied to predict the emergence and spread of particular viruses to new areas.

\section{Collection and compilation of baseline data}

Baseline data can be obtained from various websites viz. OIE, CDC, FAO, WHO, HealthMap, ProMed Mail , CD alert etc. which provides data on ongoing disease events or periodic summaries of disease status around the world and updates on evolving situation on emerging zoonoses which is crucial from prevention point of view (Saegerman et al., 2012).

Predicting viral zoonoses before they emerge into human population
Baseline data can then be analyzed to identify and manage similar locations where future virus outbreaks might be predicted to occur. Tallying and mapping zoonotic hosts is an important step to assess which animals and virus types hold the greatest potential to originate new human diseases. Hotspots may occur where many zoonotic hosts overlap in geographical range and thus their zoonotic pathogens also overlap. Morse et al., (2012) analysed database of all known emerging infectious diseases since 1940 and reported global hotspots for emerging infectious diseases that originate in wildlife. Close interaction between forest wild life reservoir and human in India makes India at high risk zone for emerging zoonoses because 2474 villages in India are inside forests; 170000 villages are around the forests and 220 million people depends on forestry for their survival (www.downtoearth.org.in). Future viral threats in India are MERS-CoV , Ebola Virus, Avian Influenza (H7N9, H9N2), Yellow fever virus, Usutu virus, Tilapia novel orthomyxolike virus, Cyclovirus and Banna Reo virus (Mourya et al., 2019). Recent report authenticating the presence of Ebola virus antibody in bats of Nagaland is a big alert to India (Dovih et al., 2019) and is an alarming bell for preparedness to face future threats.

\section{Preparedness}

Management of risks of future viral threats requires immediate surveillance of wild life reservoirs in high risk zone. Wild animal having zoonotic potential should be targeted for discovery and characterization of newer viruses before they emerge in human population. Health data of animals and persons in contact can be recorded as a means of syndromic surveillance. Indirect detection of virus is carried out by seromonitoring and subsequent confirmation by molecular techniques such as PCR. Discovery and 
characterization of viruses can be potentiated by establishment of diagnostic center for surveillance and detection of virus in the high risk area. A lesson can be learnt from Kerala where regional center of NCDC was established in Kozhikode, following outbreak of Nipah virus during 2018. Researchers from medical and veterinary faculties should ensure the development and availability of diagnostic kits and efficacious vaccines. There should be availability of medicines and other medical facilities before the occurrence of outbreaks. Multisectoral capacity building programs can be conducted for professionals so as to train them to combat upcoming threat of emerging viruses.

Global and national strategy for surveillance and prevention of emerging viruses

The ongoing Ebola virus outbreak in West Africa, the emergence of MERS-CoV, the reemergence of chinkugunya virus, the 2009 A/H1N1 influenza pandemic and 2003 SARS outbreak, all highlight the importance of large-scale infectious diseases surveillance networks. Emerging viral zoonoses is now a global issue and therefore several programs and Centers are being operated to prevent, detect and respond against emerging pathogens globally (Halliday et al., 2012) as follows:

GOARN,2000 (Global Outbreak Alert and Response Network) - WHO initiative GOARN helps in combating international spread of disease, ensuring appropriate technical assistance during outbreak, long term epidemic preparedness and capacity building.

PREDICT- USAID initiative project (2009) emerging pandemic threat programe focus on pathogen surveillance, viral discovery, and capacities strengthening in developing countries to prevent detect and control zoonoses.

GLEWS (2006)- The joint WHO- FAO-OIE Global early warning system inform prevention and control measures through the rapid detection and risk assessment of health threats of potential concern at the human-animal-ecosystem interface.

International health regulation (2005)- It provides legal health documents for international travel and transport and sanitary protection for users of international airports and ground crossings.

GDD, 2009 (Global disease detection program) of $\mathrm{CDC}$ has regional centers low resource countries including India. These centers detect and respond to emerging zoonoses. Besides, concerned in developing a global workforce, enhancing laboratory systems, increasing preparedness and communication activities and conducting public health research.

\section{Zoonotic disease surveillance in India}

In India, National Center for Disease Control (NCDC) is established at New Delhi under GDD program of CDC (ncdc.gov.in). NCDC is running integrated disease surveillance programme (IDSP) in the country for surveillance and detection of infectious diseases. There are seven regional centers in India which are located particularly in high risk zone. There are two premier institutes in India for research and diagnosis of emerging viruses first is National Institute of Virology, Pune (www.niv.co.in) which provides rapid diagnosis of emerging viruses in India and presently working as WHO reference center for arboviruses and haemorrhagic fever viruses and national monitoring center for $\mathrm{JE}$ and Influenza viruses. Another institute is National Institute of High Security Animal Diseases, Bhopal (www.nihsad.nic.in) which is working on exotic and emerging viruses including CCHF, Avian Influenza and Swine 
Influenza.

\section{Response to outbreak}

Several actions can be taken in parallel to reduce the impact of hazards produced by emerging viruses (Saegerman et al., 2012):

\section{Awareness campaigning}

Awareness campaigns addressed at professionals and the general public exposed at the risks, linked to the increasing interactions between humans and wildlife through recreational activities. Rapid means of communication such as social media, mobile apps should be used for dissemination of information related with emerging zoonoses. Also, there should be continuing education for veterinary and medical practitioners.

\section{The use of general precaution}

General precautionary measures to minimize risk of emerging zoonoses include hand washing and hygiene, personal protection while outdoors (use of face mask, mosquito repellent), food safety, and avoiding contact of pets with wild animals. Additional precautions should be adopted for young, old, pregnant and immunocompromized individuals.

\section{Biosecurity measures}

The fundamental principles of biosecurity are reducing the risk of introduction of pathogen (bioexclusion) and spread of infection (biocontainments). It can be effectively achieved by package of practices including segregation (isolation, quarantine, contact tracing), cleaning and disinfection.
Segregation is reported the most effective and disinfection the least effective.

\section{Vaccination and health management}

There is no specific treatment and vaccination for emerging viruses except few. Vaccination against Hendra virus was practiced in Australia and is also reported effective against Nipah virus (Broder et al., 2013). In India, prophylactic vaccines are available against JE (Kulkarni et al., 2018), H1N1 influenza (Murhekar and Mehendale, 2016) and KFD (Rajaiah, 2019) for use in endemic areas of the country. WHO has recently qualified Ebola virus vaccines (Vesiculo virus vector containing $\mathrm{G}$ glycoprotein of Ebola virus) for its use in african countries (Nature, 2019). Parallel participation of both veterinary and medical clinicians in the animal and human health care management would definitely reduce the impact of hazard and would provide pleasing result.

\section{One health approach}

Since, the emergence of virus occurs due to complex interaction between livestock, human and wildlife, therefore there must be involvement of professionals from various sectors with specialization in medical and veterinary virology, epidemiology, wild life researchers for sampling of animals, environmental scientist to predict the emergence of viruses, bioinformatics scientist for data analysis, public health experts for risk assessment and hazard analysis, clinicians from veterinary as well medical sectors for health management etc. Bilateral transmission of information among different sectors therefore becomes crucial which falls within the scope of One Health concept as proposed by Calvin W. Schwabe (Schwabe, 1984). 
Table.1 Taxonomy of emerging zoonotic viruses

\begin{tabular}{|c|c|c|c|c|}
\hline Family & Genus & Virus & Genome & Transmission \\
\hline \multirow[t]{6}{*}{ Flaviviridae } & \multirow[t]{6}{*}{ Flavivirus } & Yellow fever virus & ss RNA (+) & Mosquito \\
\hline & & Dengue virus & ss RNA (+) & Mosquito \\
\hline & & West nile virus & ss RNA (+) & Mosquito \\
\hline & & $\begin{array}{l}\text { Japanese enecephalitis } \\
\text { virus }\end{array}$ & ss RNA (+) & Mosquito \\
\hline & & Zika virus & ss RNA (+) & Mosquito \\
\hline & & $\begin{array}{c}\text { Kyasanur forest disease } \\
\text { virus }\end{array}$ & ss RNA (+) & Tick \\
\hline Togaviridae & Alpha virus & Chikungunya virus & ss RNA (+) & Mosquito \\
\hline Rhabdoviridae & Vesiculovirus & Chandipura virus & ss RNA (-) & Sand fly \\
\hline Nairoviridae & Nairovirus & $\begin{array}{c}\text { Crimean Congo } \\
\text { haemorrhagic fever } \\
\text { virus }\end{array}$ & Segmented SS RNA (-) & Tick \\
\hline Bunyaviridae & Phlebovirus & Rift Valley fever virus & Segmented SS RNA (-) & Mosquito \\
\hline Hantaviriadae & Hantavirus & $\begin{array}{l}\text { Hantavirus pulmonary } \\
\text { syndrome virus }\end{array}$ & Segmented SS RNA (-) & Rodents \\
\hline \multirow[t]{2}{*}{ Orthomyxoviridae } & \multirow[t]{2}{*}{$\begin{array}{c}\text { Influenza A } \\
\text { virus }\end{array}$} & $\begin{array}{l}\text { Avian influenza virus } \\
\text { (H5N1, H7N9,H9N2) }\end{array}$ & Segmented SS RNA (-) & Air borne \\
\hline & & Swine influenza (H1N1) & Segmented SS RNA (-) & Air borne \\
\hline \multirow[t]{2}{*}{ Coronaviridae } & \multirow[t]{2}{*}{ Betacoronavirus } & SARS CoV & ss RNA (+) & Air borne \\
\hline & & MERS-CoV & ss RNA (+) & Air borne \\
\hline \multirow[t]{2}{*}{ Paramyxoviridae } & \multirow[t]{2}{*}{ Henipavirus } & Nipah Virus & ss RNA (-) & $\begin{array}{c}\text { Direct } \\
\text { contact, Bat }\end{array}$ \\
\hline & & Hendra virus & ss RNA (-) & $\begin{array}{c}\text { Direct } \\
\text { Contact, Bat }\end{array}$ \\
\hline \multirow[t]{2}{*}{ Filoviridae } & Ebola virus & $\begin{array}{l}\text { Ebola haemorrhagic } \\
\text { fever virus }\end{array}$ & ss RNA (-) & $\begin{array}{c}\text { Direct } \\
\text { Contact, Bat }\end{array}$ \\
\hline & Marburg virus & $\begin{array}{l}\text { Marburg haemorrhagic } \\
\text { fever }\end{array}$ & ss RNA (-) & $\begin{array}{c}\text { Direct } \\
\text { Contact, Bat }\end{array}$ \\
\hline
\end{tabular}

Table.2 Economic impact of emerging viral zoonoses

\begin{tabular}{|c|c|c|c|}
\hline Virus & Year of outbreak & Place & Economic burden (\$) \\
\hline H5N1 Avian Influenza & 1997 & Worldwide & 30 Billion \\
\hline Nipah & 1999 & Asia & $350-400$ Million \\
\hline SARS & 2003 & South East Asia & $30-50$ Billion \\
\hline H1N1 Swine Influenza & 2009 & Worldwide & $45-55$ Billion \\
\hline Rabies & 2013 & Worldwide & 124 Billion \\
\hline Ebola & $2014-15$ & Africa & 1.6 Billion \\
\hline
\end{tabular}


Now, the time has come to convert the concept into action so as to detect, prevent and respond against emerging viruses within time. Achievements in outbreak investigation, tracing the origin of Hendra virus and breaking the transmission chain using a One Health vaccine were made possible by applying the One Health strategy in response to Hendra virus outbreak in Australia. Some more successes demonstrating the power of the One Health approach were rapid epidemiological investigation of SARS and MERS-CoV; control of Nipah virus infection in Malaysia and Bangladesh and investigation of association of a new tick bunyavirus (SFTSV) with an emerging haemorrhagic fever (Wang and Crameri, 2014). Surveillance, prevention and control program can be implemented using one health approach of cross sectoral collaboration (Belay et al., 2017) as given below:

Prioritization of zoonotic disease

Assessment of zoonotic disease burden

Zoonotic disease surveillance

Joint implementation of prevention and control strategies

\section{Challenges and future task}

Upward increasing trends of drivers of emergence, inadequate financial support for research, diagnosis, infrastructure and training, lack of manpower and resources, lack of awareness leading to underreporting of cases, inadequate research in wild life sector and lack of integration between public and animal health are the major challenges in the course of surveillance, detection, prevention of emerging viruses.

Mitigation measures enforced by laws may be adapted to prevent the increasing trend of land use change and other socioeconomic risk factors. Collaboration among national and international agencies would support low resource and low economic countries. Strengthening of digital campaigning is required for judicious reporting of suspected cases. As wild life reservoirs are major contributors of viral emergence, therefore future research may be targeted in wild animals so as to identify and characterize newer viruses before they emerge in human population. Establishment of one health institute at regional/ national level may minimize inter disciplinary distance.

In conclusion, rapid spread of emerging viruses poses threat to public health and economy. Changing trends of drivers such as land use change, climate change; global travel and trade are major challenges in the prevention and control of emerging viruses and therefore needs immediate attention. Additional consideration may be given to wild life research so as to predict newer viruses earlier than they emerge. Multisectoral One health approach can be used for effective surveillance, prevention and detection of emerging viral zoonoses.

\section{References}

Allocati, N., Petrucci, A.G., Giovanni, P.D., Masulli, M., Ilio, C.D. and and Laurenzi, V.D. 2016.Bat-man disease transmission: zoonotic pathogens from wildlife reservoirs to human populations. Cell Death Discovery, 2:16048.

Belay, E.D., Kile, .C., Hall, A.., BartonBehravesh, C., Parsons, M.B., salyer, S. and Walke, H. 2017. Zoonotic Disease Programs for Enhancing Global Health Security. Emerging Infectious Diseases, 23(Suppl 1): S65-S70.

Blancou, J. and Meslin, F.X. 2000. Brief review of the history of zoonoses. Scientific and Technical Review, 19(1):15-22.

Broder, C.C., Xu, K., Nikolov, D.B., Zhu, z., 
Dimitrov, D.S., Middleton, D., Pallister, J., Geisbert, T.W., Bossart, K.N. and Wang, L. 2013. A treatment for and vaccine againstthe deadly Hendra and Nipah viruses. Antiviral Research, 100:8-13.

Calisher, C. H., Childs, J. E., Field, H. E., Holmes, K. V. and Schountz, T. 2006. Bats: important reservoir hosts of emerging viruses. Clinical Microbiology Reviews, 19: 531-545.

Centers for Disease Control.1991. Aedes albopictus introduction into continental Africa. Morbidity and Mortality Weekly Report, 40:836-838.

Chapman, C.A., Gillespie, T.R. and Goldberg, T.L. 2005. Primates and the Ecology of their Infectious Diseases: How will Anthropogenic Change Affect HostParasite Interactions? Evolutionary Anthropology: Issues, News, and Reviews, 14:134-144.

Cook, N. 2013. Viruses in Food and Water: Risks, Surveillance and Control. Cambridge, UK: Woodhead Publishing.Pp 445.

Domingo, E.2010. Mechanisms of viral emergence. Veterinay Research, 41(6):38.

Dovih,P., Laing,E.D., Chen,Y., Low,D.H.W., Ansil,B.R., $\quad$ Yang,X., Shi,Z., Broder,C.C., Smith,G.J.D., Linster,M., Ramakrishnan,U. and Mendenhall, I.H.2019. Filovirus-reactive antibodies in humans and bats in Northeast India imply zoonotic spillover. Plos Neglected Tropical Diseases, 13(10): e0007733.

Eisen, R. J., Kugeler, K. J., Eisen, L., Beard, C. B. and Paddock, C. D. 2017. TickBorne zoonoses in the United States: Persistent and emerging threats to human health, Institute for Laboratory Animal Research Journal, 1-17.

Enria, D.A. and Pinheiro, F. 2000. Rodentborne emerging viral zoonosis.
Hemorrhagic fevers and hantavirus infections in South America. Infectious Disease Clinics of North America, 14(1):167-84.

Graham, R.L. and Baric, R.S. 2010. Recombination, reservoirs, and the modular spike: mechanisms of coronavirus crossspecies transmission. Journal of Virology, 84: 3134-3146.

Haggett, P. 1994. Geographical aspects of the emergence of infectious diseases. Geografiska Annaler, Series B: Human Geography, 76(2): 91-104.

Halliday, J., Daborn, C., Auty, H., Mtema, Z., Lembo, T., Bronsvoort, B.M., Handel, I., Knobel, D., Hampson, K. and Cleaveland, S. 2012. Bringing together emerging and endemic zoonoses surveillance: shared challenges and a common solution. Europe PubMed Central, 367(1604): 2872-2880.

Jones, K.E., Patel, N.G., Levy, M.A., Storeygard, A., Balk, D., Gittleman, .L. and Daszak, P. 2008. Global trends in infectious diseases. Nature, 451:990993.

Keiser, J., Maltese, M.F., Erlanger, T.E., Bos, R., $\quad$ Tanner, M. and Singer, B.H. 2005.Effect of irrigated rice agriculture on Japanese encephalitis, including challenges and opportunities for integrated vector management. Acta Tropica, 95:40-57.

Klauder, J. 1958. Interrelations of human and veterinary medicine. New England Journal of Medicine, 258: 170-177.

Kulkarni, R., Sapkal, G.N., Kaushal, H. and Mourya, D.T. 2018.Japanese Encephalitis: A Brief Review on Indian Perspectives. The Open Virology Journal, 12: 121-130.

Kupferschmidt, K. 2017. Hunting Ebola Among Bats in the Congo. Science.

LeDuc, J.W., Childs, J.E. and Glass, G.E. 1992. The Hantaviruses, etiologic 
agents of hemorrhagic fever with renal syndrome: a possible cause of hypertension and chronic renal disease in the United States. Annual Review of Public Health, 13:79-98.

Loh, E.H.,ZambranaTorrelio, C., Olival, K.J., Bogich, T.L., Johnson, C.K., Mazet, J.A.K., Karesh, W. and Daszak, P. 2015. Targeting transmission pathways for emerging zoonotic disease surveillance and control. Vector-borne and Zoonotic Diseases, 15:432-437.

Mansfield, K.L. , Jizhou, L. , Phipps, L.P. and Johnson, N. 2017. Emerging tick-borne viruses in the twenty-first century. Frontiers in Cellular and Infection Microbiology, 7 : 298.

McFadden, G. 2005. Poxvirus tropism. Nature Reviews Microbiology, 3:201-213.

Morse, S.S., Mazet, J., Woolhouse, K. A, M., Parrish, C.R., Ca rroll, D., Karesh, W.B., ZambranaTorrelio, C., Lipkin, W.I. and Daszak, P. 2012. Prediction and prevention of the next pandemic zoonosis. Lancet, 380:1956-1965.

Mourya, T.D., Yadav, P.D., Ullas, P.T., Bhardwaj, S.D., Sahay, R.R., Chadha, M.S., Shete, A.M., Jadhav, S., Gupta, N., Gangakhedkar, R.R., Khasnobis, P. andSingh, S.K. 2019. Emerging/reemerging viral diseases \& new viruses on the Indian horizon. Indian Journal of Medical Research, 149: 447-467.

Murhekar, M. and Mehendale, S. 2016. The 2015 influenza A (H1N1) pdm09 outbreak in India. Indian Journal of Medical Research, 143(6): 821-823.

Nakajima, K. 2003. The mechanism of antigenic shift and drift of human influenza virus. Japanese Journal of Clinical Medicine, 61(11): 1897-1903.

Nature. 2019. First vaccine against deadly Ebola virus wins approval. Nature, 575:425-26.

Neumann, G., Noda, T. and Kawaoka,
Y.2009. Emergence and pandemic potential of swine-origin H1N1 influenza virus. Nature, 459 : 931-939.

Rajaiah, P. 2019. Kyasanur Forest Disease in India: innovative options for intervention. Human Vaccines and Immunotherapeutics, 15(10):22432248.

Rohr, J.R., Barret, C.B., Civitello, D.. and Craft, M.E. 2019. Emerging human infectious diseases and the links to global food production. Nature Sustainability, 2:445-456.

Rossati A. 2017.Global warming and its health impact. International Journal of Occupational and Environmental Medicine, 8:7-20.

Ryu, W. 2017. New Emerging Viruses In book: Molecular Virology of Human Pathogenic Viruses. pp.289-302.

Saegerman, C., Dal Pozzo, F. and Humblet, M. F. 2012. Reducing hazards for humans from animals: emerging and reemerging zoonoses. Italian Journal of Public Health, 9:13-24.

Schwabe, C.W. 1984. Williams and Wilkins; Baltimore.Veterinary Medicine and Human Health.

Sharma, V., Kaushik, S., Kumar, R., Yadav, J.P. and Kaushik, S. 2018. Emerging trends of Nipah virus: a review. Reviews in Medical Virology, 29:201015.

Smith, I. and Wang, L.F. 2013. Bats and their virome: an important source of emerging viruses capable of infecting humans. Current Opinion in Virology, 3(1):84-91.

Smolinski, M.S., Hamburg, M.A. and Lederberg, J. 2003. Microbial Threats to Health: Emergence, Detection, and Response. Washington DC: Institute of Medicine, National Academies Press.

Talukdar, B., Sikarwar, A. and Ambade, M. 2018. Deforestation in Kerala over a quarter century (1993-2017) and the 
outbreak of Nipah Virus: an analysis using remote sensing technology and GIS approach. Research in Environment and Life Sciences, 11(11): 285-291.

Taylor, L.H., Latham, S.M. and Woolhouse, M.E.J. 2001. Risk factors for human disease emergence. Philosophical Transactions of the Royal Society B, 356:983-989.

Wang, L.F. and Anderson, D.E.2019.Viruses in bats and potential spillover to animals and humans. Current Opinion in Virology, 34:79-89.

Wang, L.F. and Craneri, G. 2014. Emerging zoonotic viral diseases. Scientific and Technical Review, 33:569-81.

Weaver, S.C. and Reisen WK. 2010. Present and future arboviral threats. Antiviral Research, 85(2):328-45.

WHO (2018). Annual review of diseases prioritized under the Research and Development Blueprint, Informal consultation 6-7 February 2018 Geneva, Switzerland.

WHO, FAO and OIE. 2004. Report of the WHO/FAO/OIE joint consultation on emerging zoonotic diseases, 3 to 5 May, Geneva,Switzerland.

Wilson, M.L. 2001. Ecology and infectious disease, in Ecosystem Change and Public Health: A Global Perspective, J.L. Aron and J.A. Patz, Editors.Johns Hopkins University Press: Baltimore, Pp. 283-324.

World Tourism Organization .2011. Tourism Towards 2030 Global Overview. Advance edition presented at UNWTO 19th General Assembly - 10 October 2011.

\section{How to cite this article:}

Chandrahas Sannat, Nidhi Rawat, Amit Kumar Gupta, Poornima Gumasta and Hirpurkar, S. D. 2020. Emerging Trends of Viral Zoonoses: A Problem Needs Solution. Int.J.Curr.Microbiol.App.Sci. 9(01): 1523-1536. doi: https://doi.org/10.20546/ijcmas.2020.901.170 